\title{
Independence of Chondriosomes from Nuclear Matter
}

\author{
by Petr F. Milovidov, R.N.D. \\ Plant Physiological Institute, Charles University, \\ Prague, Czechoslovakia
}

Received October $17,193^{2}$

The discovery of chondriosomes in vegetative cells (MEvEs 1904) fell in with the full bloom of the chromidial theory expounded by R. Hertwig $(1898,1899,1902$ etc.) and his followers. No wonder therefore that, owing to the imperfect microtechnical methods of the time, the majority of chondriosomes was described as "chromidia", that is particles of chromatin going out of the cell nucleus into the cytoplasm. At that time these chromidia were considered as of universal importance : all cell structures were said to generate from them or with their help. Thus f.i. GoldschmidT $(1904,1905)$ considers the formations he found in the cells of different tissues of Ascaris as chromidia ("Chromidialstränge"), their whole as "Chromidialapparat" and identifies them with mitochondria and chondriomits. DERSCHAU in a number of works $(1904,1907,1909,1910,1911,1914)$ was specially occupied with chromidia in plants. The main point of his views is this. The nucleolus appears to be a store matter of a general character and the centre of all the vital phenomena of the cell, it is in close connection with the formation of the kinoplasmic structures and with chromatin ${ }^{1)}$. The protuberances of linin, generated from the nucleolus, penetrate into the walls of the alveoles of cytoplasm ("Wabenwände") and along these ways, inside the linin, proceed the particles of basichromatin.

Depending on the degree of impregnation of these walls with nuclear matters (nuclein and plastin) there result different cell structures : ergastoplasm, kinoplasm, mitochondria, microsomes etc. Also the chloroplasts, centrioles, blepharoplasts, pyrenoids are, according to DERSCHAU, nuclear derivatives. Plastids generate as follow: the

1) Other works on this subject see in KoERNICKE's review (1903). 
nucleus emits into the cytoplasm sprigs which get green at the tips and get surrounded by a belt of starch. DERSCHAU's views are not always clear and had evidently undergone a certain evolution before stopping at the above mentioned conception. Thus at first (1904) he only connects the nucleolus with the formation of kinoplasmic structures on one side and with chromatin on the other. Later (1907) he speaks of the linin sprigs of the nucleus and of the movement therein of mitochondria similar to the mitochondria of MEVES and TISCHLER, later still (1909) of the exit of chromatin protuberances into the cytoplasm and the formation out of them of rod-like chromidia which he connects with chromosomes, etc. TISCHLER (1906) explained the mitochondria he discovered in tapetum-cells of hybrids of Ribes, by the exit of the chromidial matter into the cytoplasm. MORoff (1909) on the ground of theoretical speculations, held that also the chloroplasts of plants generate from the nucleus. Owing to his influence SCHILLER (1909) examined this problem and discovered that in the embryo-cells of Triticum and Phaseolus the plastids at first are entirely absent and form later by means of the fragmentation of the nucleolus and pushing these fragments into the cytoplasm. ${ }^{1)}$

SCHILLER is inclined to follow MorofF's hypothesis that the system of plastids in plant cells corresponds to the macronucleus and to "Dotterkern" in animals and that the vegetative cells are binucleate in this sense. STAUFFACHER $(1910,1911)$ expounds views similar to those of Derschau. ARNOLDI and BoEnicke (1911) find a genetic connection between the mitochondria and the nucleus in higher plants. ARNOLDI (1913) states the connection of the cell nucleus with chromatophore and pyrenoids in the alga Dictyosphaeria and is inclined to admit an organic connection of mitochondria with the nucleus. HIRSCHLER (1913) admits also the transmission of certain nuclear matter into chondriosomes in the sex-cells of the Ascaris. MorofF (1915) describes the exit of chromidia into the cytoplasm and their transformation into different cell-structures in Sarcosporidia.

It is curious to note that SCHILLER (1911) having stated in the alga Antithamnion the exit of the nucleoli into the cytoplasm, did not dis-

1) Thus one described several manners of the formation of plastids out of the nucleus. According to DERSCHAU they are formed as sprigs of the nucleus, according to SCHILLER the plastids are formed from fragments of the nucleolus. The present theory derives the plastids from chondriosomes, which are autonomic. Inasmuch as the former chromidia were our chondriosomes the hypothesis of plastids generating from them is correct. The fundamental difference is this, that the mitochondria has nothing in common with the nucleus and does not generate from it; it is true that even the manner of formation was then quite differently conceived. 
cover in it any chromidia and could not find it possible to ascribe the strongly stained grains to the nuclear substance. NĚMEC (1910), at the time when the enthusiasm for the application of the chromidial theory to chondriosomes was at its highest, writes: "Die Mitochondrien als Chromatin zu bezeichnen halte ich für unrichtig" (p. 166).

AleXeIEFF (1917) in a series of works on Flagellata strives to prove that all the cell-structures are formed at the expense of mitochondria. The latter, according to ALEXEIEFF, in their turn are not autonomic, as the majority of investigators suppose, but originate from the nucleus as chromidia : "....les mitochondries (ou chromidies) sont en somme des chromosomes (ou des chromidies) qui, cependant, changent sans cesse de constitution et toujours dans un même sens : celui de la simplification à la suite de processus de dédoublement" (1917 d, p. 361). Blepharoplast, flagellum, myofibrills, cilies, ergastoplasm, parabasal body, pyrenoids, grains of metachromatin, starch, fats, glycogen-all these are formed from derivatives of the nucleus : chromidia. In cases where the autonomy of the mitochondria and of the blepharoplast is indisputable, this author always attributes to them a nuclear origin though phylogenetic.

According to A. MEYER (1920) the chondriosomes, called by him "Allinante", have for the cytoplasm the same meaning as nucleolus for the nucleus.

A list of such works could be considerably enlarged, especially if one takes into consideration the zoological bibliography. This is not our problem; I will only add that since S. NAWASCHIN's work upon Plasmodiophora brassicae (1899) the doctrine about the chromidia has once more found a good soil for its propagation and that there is scarcely any work upon the organisms related to it without the description of a peculiar "chromidial stage" (see also MiLovidov 1931).

All these arguments concerning the genetic relationship of chondriosomes and nuclear substance in one or another way are perfectly inconsistent. Indeed, the chief proof of the issue of the chondriosomes from the nucleus was their intense staining with iron-hematoxylin and their proximity to the nucleus. It is quite evident that both these proofs are purely external. At present it is at the least naive to consider that all which stains by means of iron-hematoxylin to a deep black colour, belongs to the nuclear matter (chromatin); one must not forget that even some metaplasmic inclusions are thus stained, for

1) The spacing is ours. 
instance the cristalloids of albuminoids etc. The immediate vicinity of the chondriosomes to the nucleus can be explained purely by physical laws, the chondriosomes often stick also to the vacuoles, the cellmembrane, etc. and are found not only near the nucleus, but are dispersed all through the cytoplasm ; on the other hand around the nucleus there may also gather other cell-formations. Except for a similar stain with iron-hematoxylin the chondriosomes have very little in common with the nucleus. The fact that the Janus green solution stains in vivo the chondriosomes and does not stain the chromatin of the nucleus speaks in itself of the great difference of their physico-chemical nature. The various methods of the differential staining also allow easily to distinguish the chondriosomes from the nuclear matter (chromosomes, fragments) on the histological preparations. For instance when using VoLKONSKY's staining method the mitochondria always take acid-fuchsin (ruby-red colour) whereas the chromatin takes the basic UnNA-blue or a corresponding mixture (blue or greenish blue colour); when using acid-fuchsin and methyl-green, chondriosomes also take the first stain. Paracarmine stains the nucleus and deos not stain the mitochondria (NĚMEC, 1910, p. 166). The heating of the objects to a degree of $50^{\circ} \mathrm{C}$ in most cases destroys chondriosomes entirely and conserves the nucleus; acetic acid, absolute alcohol destroy or greatly alter chondriosomes and on the contrary fix the nuclei. The fact that any good nuclear fixatives destroy chondriosomes (NAWASCHIN, CARNOY, sublimat-acetic etc.) is the reason why even the best cytologists of their time did not discover these elements, for demonstrating them special "preserving" liquids were needed. There are many other differences well known to every practised cytologist. On the easy changeability of chondriosomes, which was traced sometimes also in vivo, and their disappearance upon histological preparations there exists a whole literature, to which those interested can refer (GuiLLIERMOND, LEwITSKY, CowDRY a.o.). On the other hand the histological constancy of the nucleus is well known.

Fauré - Fremiet (1910), Mascré (1921), Rumiantzev (1922), LEWITSKY (1924) and others have proved that the majority of what was supposed to be chromidia were real chondriosomes, in other cases these were store- and other substances, metachromatic granules, even foreign organisms (parasites) ${ }^{1)}$. In these cases the nucleal reaction was a great help.

1) For details and literature see LEWITSKY and DofLEIN-REICHENow. 
MiLovidov (1931) believes that the so-called "acaryote" or "chromidial" stage does not exist at all in Plasmodiophora brassicae. In Plasmodiophora, Olpidium and Myxomycetes with the aid of the nucleal reaction of FEULGEN AND ROSSENBECK he was not able to discover any. thing similar to nuclear chromatin in the cytoplasm. About this he mentions elsewhere (see also preliminary communication 1932).

Generally all the doctrine on chromidia is at present entirely unacceptable (comp. BĚLAŘ, DOFLEIN-REICHENOW a.o.). On the other hand at present it is hard to doubt the autonomy of the mitochondria (see f. i. GUILLIERMOND and MANGENOT): their presence in every normal cell and the division, easily observed in vivo, does not leave any doubts in it, at the same time nobody has yet proved their formation de novo. ${ }^{1)}$

Notwithstanding all this in the latest years there reappear new works which endeavour to prove the nuclear origin of chondriosomes and their chromatin nature. One also tries in the same way to connect the strong staining with iron-hematoxylin with a clear fuchsinophily of mitochondria and therefore they often speak not of their direct origin from chromatin particles, but from the nucleolus or from a $\mathrm{ch}$ anged chromatin. These views remind one very much of the old conceptions of DERSCHAU, ALEXEIEFF and others.

So for instance SAGUCHI (1927) in the cells of tissue cultures of the hen's ernbryo finds that the nucleolus is capable of accepting and emitting particles of chromatin and that the chondriom is formed by means of transformation in the nucleolus, its elements move through the linin fibers from the nucleus into the cytoplasm. HoLlande (1927) holds that the siderophilic inclusions in the cytoplasm of Blastocystis enterocola which ALEXEIEFF described as mitochondria, originate from the nucleus and are real chromidia. DEHORNe and HOSSELET (1928) endeavour again to prove on animal objects the genetic connection between the nucleus and the mitochondria. I will allow myself to linger on those works. These authors describe the exit of the nuclear matter into the cytoplasm of the spinning glands cells in some Phryganida, its masses they compare with nucleolus, call the "le nuclé o-roug e" (the nucleolar red) and from them derive mitochondria. Prenant (1897) saw such masses in Isopoda and deemed that they are matter absorbed by the cells. Generally the data of these

1) LEWITSKy (1924) deems possible in some cases their growth from particles unseen, but preexisting in the cytoplasm even to dimensions visible to our eye. 
authors are uncertain. Thus for instanee, when using the VoLkONSKY's staining method they obtained the following distribution of colour: the nucleoli-intense blue, masses in the cytoplasm-red (acid-fuchsin), masses lying on the periphery of the nucleus in the zone where the limits of the nucleus disappear, sometimes adopt an intermedial stain varying from blue to red. On account of this the authors conclude that the chromatin of the nucleoli(?) is gradually transformed into fuchsinophilic matter issued into the cytoplasm. VolKonsKY's staining gives distinct results only when considerable routine is attained, as over-staining with blue often obtains intermediary shades. Therefore it is rather hazardous to derive such cardinal conclusions on the transformation of matters only on the basis of VolkoNskY's method. Staining with acid-fuchsin or iron-hematoxylin does not give us any right, notwithstanding the opinion of these authors, to consider the blocks in nucleus as nucleoli, as hematoxylin generally stains many things in black. Acid-fuchsin stains also the chromatin, as long as it is not covered with blue, which is easy to see in the microscope. On the other hand, by this method it is chromatin that gets stained into blue or greenish-blue and thus the described blocks were most likely chromatin, having nothing in common either with the fuchsinophilic masses in the cytoplasm, nor with real nucleoli. Masses in the cytoplasm are evidently partly some products of the metabolism and partly deformed chondriosomes stuck together. Under intra vitam staining with a mixture of Janus green and neutral red, according to the authors, the neutral red sometimes stains the granulous masses on the border of the nucleus and the cytoplasm, the masses already "issued" into the cytoplasm also adopt traces of Janus green. As is known the neutral red in vivo stains only the vacuoles (and seldom some of the fats) and therefore these masses can in no way be identified either with the nucleoli or with chromatin. On the other hand Janus green in vivo stains chondriosomes, which fact confirms their participation in the "formation" of the cytoplasmic masses. Thus the author's conclusion that examination in vivo proves the issue of the nucleolus into cytoplasm is for us both incomprehensible and inacceptable.

HosSELET $(1929,1930)$ sustains in a number of later works the same hypothesis concerning the fragmentation of the nucleolus, the issue of these fragments into the cytoplasm and their transformation into mitochondria (comp. Schiller 1909). The nucleoli, according to HosseLET, are fuchsinophilic from within and azurophilic on the periphery. The indication of the author, that the nucleoli are entirely 
azurophilic in slightly differentiated preparations ${ }^{1)}$ and become by degree of differentiation fuchsinophilic in the centre, lead one to suspect, that HOSSELET had to do with a rather common artifact. The nucleolus, several structures in the cytoplasm and also the cytoplasm itself when deeply stained with blue adopts sometimes this dye and often unevenly ${ }^{2)}$; by degree of differentiation the acid-fuchsin staining transpires, finally by means of full decoloration one can entirely remove the blue and so on. HosseleT's complicated conception: azurophilic nucleolus $\rightarrow$ fuchsinophilic nucleolus $\rightarrow$ nucleolar red $\rightarrow$ chondriom is implausible. On the contrary it is easier to admit that chondriosomes when degenerating, can stick together forming irregular fuchsinophilic lumps (nucleolar red) and this degeneration would easily explain the small quantity of chondriosomes in the cytoplasm at the moment when the masses appear, as HosSELET describes it. It is possible that in the formation of "nucleolar red" also secretions or other inclusions of a fuchsinophilic character participate, finally a degenerative process of the issue of the nucleolus and its fragmentation within the cytoplasm is very possible, to which Hosselet himself indicates a literature. But the chromatin of the nucleus, as well as the nucleolus, are in no way connected with the elements of chondriom. In other works HOSSELET treats also the GoLGI apparatus as evolution forms of chondriosomes and thus makes it depend on the nucleoli and derives some of the inclusions also from the nucleus. The majority of HoSSELET's analogues are based only on the similarity of the acid-fuchsin staining and are not convincing.

HIRSCHLER (1929) discovers in the spermatocytes of Lepidoptera, that the nucleus by means of a specific basophilic nucleolus secretes nuclear matters (chromatin, sap) which pass in the remains of the spindle and from there to the cytoplasm and are there transformed into elements of vacuome and the GoLGI apparatus. Besides in the spermatids of Palomena viridissima also the mitochondrial body (corps mitochondrial) which includes part of the spindle and of the nuclear sap, takes part in the transport of the nuclear matter and the formation of the "second GoLGI apparatus" (" appareil de GoLGI secondaire").

RADU (1930) finds mitochondria even in the nucleus(!). In the gland cells of the vas deferens of Armadillidium vulgare LATr. he describes the following fantastic processes. The nuclei contain 1-5 " nuclé-

1) The spacing is ours.

2) According to HOSSELET this must prove the fusion of the azurophilic ring of the nucleolus with the cytoplasm(!). 
oles plasmatiques" sometimes homogenic and sometimes containing small bodies which he mistakes for " nuclear mitochondria" and which always look like dictyosomes. The nucleoli also contain vacuoles and secretions. In the nucleus itself one can also meet with small bodies composed of a fuchsinophilic centre surrounded by a light blue ring of grains (VoLKONSKY's staining). RADU states that "Par la réaction de FEULGEN pour l'acide thymonucléique, leur péripherie est colorée en violet, tandis que le centre reste incolore." $\mathrm{He}$ thinks that mitochondria are formed "à l'aide ou aux dépens de la chromatine" and pass into the cytoplasm.

Of course it is impossible to agree with such a treatment of the subject. First of all it is incomprehensible why RADU connects the origin of chondriosomes with chromatin : chondriosomes are fuchsinophilic and give no nucleal reaction, therefore it would be simpler to connect their origin with some fuchsinophilic matter, though this connection would not go further than a similarity in coloration by means of the acid-fuchsin or so. This author himself acknowledges that he did not succeed to state the issue out of the nucleus of the above named "nucleoli," but only the issue of the ready chondriosomes (?). Thus, according to RADU, chondriosomes derive from two types of nucleoli: from the usual fuchsinophilic ones and from special nucleoli, supplied with chromatin rings. If the nucleal reaction was not a pseudoreaction it would only prove that these are simply particles of chromatin collected in a ring. E. g. in the nuclei of the root-cells of the turnip (Brassica oleracea gongyloides) attacked by Plasmodiophora brassicae or in the macronucleus of Chilodon (REICHENow, 1928, S. 151, pl. 4 , fig. 3,6 ) the particles of chromatin have also sometimes an aspect of hollow globules or rings. As RADU describes in the nucleoli vacuoles and grains of secretions, he might mistake vacuolar precipitates, which often form half-moons (dictyosomes) on the periphery of the vacuoles, for a special kind of chondriosomes.

Thus the views of DERSCHAU, SCHILLER and other authors are revived almost in the same conception. As we have seen there were very broad generalisations developed. The mitochondria must originate either at the expense of chromatin or the nucleolus or at the expense of the fuchsinophilic matter which was formed out of chromatin (the old tendency towards the similarity of staining). Formerly a direct issue of the chromatin particles into the cytoplasm was supposed and its transformation into mitochondria or its imbibition with nuclear substance (DERSCHAU, HIRSCHLER) so that chondriosomes adopt an external 
likeness to the nuclear matter (iron-hematoxylin staining). At present one tries more often to prove the transformation of chromatin into a fuchsinophic matter in order to connect the similar staining of the chondriosomes and the nucleoli or their centres (acid-fuchsin staining). In the recently published book by P. A. DANGEARD (1931) we also find a remarkable statement concerning chondriosomes, which he calls cytosomes: "Bien que nous n'ayons fait aucune recherche microchimique, nous estimons que la substance qui constitute ces cytosomes renferme beaucoup de chromatine: la chose nous paraît probable à cause de la teinte franchement noire foncée prise parfois par ces éléments avec la méthode d'HEIDENHAIN et qui ne diffère pas sensiblement de celle que prennent les chromosomes eux-mêmes" (p. 417). Therefore DANGEARD also calls them "chromatinosomes." Thus a similar staining with iron-alum-hematoxylin is enough for this investigator to place chondriosomes on a level with chromosomes. On the contrary the absence of staining in strongly differentiated preparations leads to the conclusion that the chromatin vanish. So LENOIR (1932) describes that at the time of diakinesis in Equisetum palustre chromosomes lose chromatin and become entirely achromatic and later collect chromatin anew. LENOIR comes to the conclusion that the chromosomes contain two substances: the fundamental, morphologically remaining and transferable from one nuclear generation to another (linin) and the other (chromatin), which is a product of the activity of the first. Thus the hypotheses concerning the issue of chromatin from the nucleus in lower organisms are crowned with the hypothesis of its disappearance in higher plants.

It is indubitable that the majority of the above enumerated hypotheses are based on microtechnical methods of examination not exact enough and on an insufficient critical judgment of things, seen in the preparations, and also on an insufficient acquaintance with the original literature. It is not fair to state, as was often noted, a generative connection of structures only because they are placed side by side and often take an identical colour when stained with the same dye. As we see, the authors of such works give no proofs of the transformation of the nuclear matter into chondriosomes, except a likeness (and this not always) of the staining. In a contrary case they refer to complicated hypotheses of the transformation of matters. The connection and explanation of some of the facts is very doubtful and partly absolutely wrong. Moreover their point of view does not agree with the current and already proved views on the nature of the chondrio. somes and the nature of the nucleus. 
One could pay such arguments and hypotheses no attention, but unfortunately they penetrate into the works of other solid investigators and even into serious monographs or manuals (f.i. KIESEL 1930), where often they are quoted on a level with valuable works or even quite alone. The danger of a new "Chromidien-Epidemie" (SCHILLER 1911) induces me once more to draw attention to the erroneousness of the conception which identifies chondriosomes with the chromatin of the nucleus.

The most characteristic feature of the nuclear substance is the presence in it of the thymonucleic acid, proved by means of the socalled nucleal reaction of FEULGEN and ROSSENBECK. I have made a number of experiments in order to define the presence or the absence of this acid in chondriosomes ${ }^{1}$.

It would seem, that from the very electivity of the nucleal reaction derives the conclusion of the negative reaction of the other cellelements, consequently of the chondriosomes. But just as regards the chondriosomes the problem is somewhat more complicated. It is known that they are extremely fragile and are easily destroyed just by those fixatives which are admitted during the nucleal reaction: alcohol and sublimate-acetic mixtures. Thus the absence of chondriosomes staining in the preparations, submitted to nucleal reaction, could be explained not by the absence in them of the thymonucleic acid, but simply by the absence of chondriosomes. This absence in itself does not allow their comparison with the chromatin. But even in case of their preservation after fixation another question offers itself, namely : are not the mitochondria destroyed when hydrolysed in hydrochloric acid by heating? Otherwise only those experiments may be considered entirely demonstrative where the presence of the chondriom-elements after fixation and after hydrolysis at different duration can be proved. On the other hand the so called chondriosomic fixatives, that is liquids which preserve them well, are not admitted in proving the thymonucleic acid, because they contain chromic acid and formalin. FEULGEN (1926, p. 1070) recommends to avoid chromic acid, as an oxydating substance and consequently capable of bringing the ruin of nucleal matters, and to avoid formalin as a solution of the aldehyde, which gives together with SCHIFF's liquid the same violet reaction. Therefore I act as follows :

First of all I used the root-tips of peas (Pisum sativum) which were killed by NĚMEC's mixture $(1 \%$ chromic acid, $1 \%$ potassium

1) See preliminary communication 1932. 
bichromate and formalin) which well preserves the mitochondria. Having chosen a certain object I saw upon slides, stained with ironhematoxylin, the presence of a quantity of well fixed elements of chondriom. After this, a series of preparations was made out of the same piece, each pair of which was submitted to hydrolysis the same number of minutes; then one of the preparations was sunk into a fuchsin-sulfuric acid solution and the other was rinsed in distilled water, was mordanted in 3\% iron-alum and was stained with ironhematoxylin. The preparations stained with hematoxylin allow one to state, that the hydrolysis evidently does not change markedly the structure and the staining of the chondriosomes. On preparations submitted to nucleal reaction there was not a trace of the staining of chondriosomes; whereas the nuclei were stained in the typical violet colour, the same as after the usually recommended fixatives: precisely and electively, though somewhat weaker (comp. BERG, KUHLENBECK and VoIT). Some preparations were preliminarily kept in $96 \%$ alcohol in order to prevent the possibility of the plasmal reaction. The duration of the hydrolysis was: $5,6,7,8,9,10,11,12$ and 15 minutes, the duration of fuchsin-sulfuric acid staining $2-2 \frac{1}{2}$ hours.

Thus: 1) the typical nucleal reaction of the nucleus is manifest also after a fixative containing chromic acid has been used, and consequently the absence of staining of chondriosomes does not depend on the use of unsuitable fixation, capable of destroying the nucleal matter,

2) the absence of nucleal reaction of the chondriosomes does not depend on the extraction of the nucleal matter by hydrolysis and

3 ) it also cannot be explained in this case by the destruction of the chondriom-elements during fixation.

It follows therefore, that the nucleal reaction is not successful on the chondriosomes in virtue of the nucleal matters being absent in them. That this cannot be explained by accidental reasons, for instance the destruction of chondriosomes in one preparation and their conservation in the other of the same pair, can be easily proved in the following way. The preparation, submitted to nucleal reaction, on which microscopical examination does not show anything, except nuclei, is submitted to re-staining. The cover-glass is unglued with the aid of xylol, the preparation is washed in xylol, alcohols, water, is mordanted in $3 \%$ iron-alum solution and stained in HEIDENHAIN's hematoxylin, is differentiated with $1 \%$ iron-alum, washed, dehydrated and is mounted as usual into Canada-balsam. When examin- 
ing through the microscope one sees a great number of well pronounced chondriosomes of all kinds. Such a method of restaining ${ }^{1)}$ gives a full proof, that the elements of the chondriome in the preparations are present, but do not come forth with the aid of nucleal staining. However the deviation from the standard fixation before nucleal reaction, just the use of aldehyde (which would rather strengthen the reaction) can all the same furnish matter for disputing the justness of our results. Therefore I had recourse to a straight and exact proof of the anucleality of chondriosomes, profiting by the fact that chondriosomes of some plants (e. g. in the cells of the turnip roots) prove to be resistant when not special chondriosomic fixatives are applied. Therefore having used in this case the standard fixative for nucleal reaction, which I had many a time tried when using this reaction, namely a mixture of $100 \mathrm{p}$. saturated sublimate with $2 \mathrm{p}$. of glacial acetic acid during 24 hours, I found in the turnip cells a large quantity of typical chondriosomes, chiefly grains or short rods and sometimes filamentous chondrioconts.

In this case also a series of experiments were made. Pairs of preparations were submitted to hydrolysis during $5,6,7,8,9,10,11,12$, 15 and 20 minutes, then one of them in each pair was treated further on the nucleal reaction by SCHIFF's solution (from 2 to 24 hours) and so on, the other washed in water, was mordanted in alum and stained with iron-hematoxylin, differentiated etc. Not on one of the preparations, submitted to nucleal reaction, was found staining of chondriosomes, but only the staining of the nuclei, and sometimes a slight pseudostaining of same cell-walls. On the contrary on preparations stained with HEIDENHAIN's hematoxylin was found a quantity of typical chondriosomes stained in black or gray. In this case we also applied re-staining which invariably showed the chondriosomes of different types. Finally also the saturated aqueous corrosive sublimate sometimes fixes mitochondria. On several onion (Allium cepa) roottips I managed to obtain a satisfactory fixation of chondriosomes. If sometimes by this fixation there proceeds a certain alteration chiefly fragmentation to grains, then in this case it does not play any role, as here it is not the form but the substance of chondriosomes that matters. Having submitted several preparations to a five-minute hydrolysis in normal $\mathrm{HCl}$, I treated one of them in fuchsin-sulfuric acid solution and

1) After mordanting in iron-alum the nucleal staining does not disappear, which one can easily prove under microscope; thus iron-hematoxylin redyes the staining of the nuclei and lends additional colour to mitochondria and other elements. 
did not receive any staining of mitochondria, others I mordanted after the hydrolysis in alum and stained them in iron-hematoxylin and in these cases I found all the types of chondriosomes, also chondrioconts. The method of re-staining gives also here very good results. One can also restain in acid-fuchsin : after the removal of the cover-glass and a final rinsing of the preparation in distilled water one stains it with acid-rubin and differentiates it by means of an alcoholic solution of aurantia (see VolKonsKY's method). The large quantity of preserved chondriosomes is stained in a marvellous ruby-red.

In Myxomycetes and Plasmodiophora the chondriosomes are sometimes partly preserved together with different inclusions after no specially chondriosomic fixatives. Here too the nucleal reaction does not show either any chondriosomes or any grains of extranuclear chro. matin, of which many authors speak. After re-staining with HEIDENHAIN's iron-hematoxylin we almost always find the rests of mitochondria and other black-stained inclusions.

Thus our experiments prove without doubt that in keeping to all the rules of a histo-chemical demonstration of the thymonucleic acid by the nucleal reaction method, the chondriosomes of all types in plants do not give this reaction ${ }^{1)}$, whereas the nuclei give it in a high degree. Also one can prove that the elements of chondriom are present in a so to say "latent" i. e. unstained state on such preparations submitted to nucleal staining, and can be demonstrated by means of a simple re-staining of the preparations in iron-hematoxylin. Thus is obtained a new proof of the absence of "chromatin" in the chondriosomes and therefore all speculations tending to prove their origin at the expense of nuclear chromatin must be abandoned as non scientific.

\section{Summary}

1. The latest attempts to connect the chondriosomes with nuclear matter must be considered just as inconsistent as the previous ones.

2. The chondriosomes of the vegetative cells give a negative nucleal reaction and therefore do not contain any thymonucleic acid which is the most characteristic element of the cell nucleus.

1) The negative nucleal reaction is one more proof of the difference between them and bacteria, the symbiotic ones for instance. In our experiments the nucleal reaction is positive on Bact. radicicola in the root-nodules of Lupinus and some other not identified bacteria in the root-tips of different plants. But even with strong enlargement it is hard to discern the localisation of the staining. 
Yet the absence of nucleal reaction of the chondriosomes does not depend on their destruction during fixation or the hydrolysis, as a simple restaining of the preparations with iron-hematoxylin or acidfuchsin can prove their presence.

3. Chondriosomes do not contain any "chromatin" and are not in any genetic connection with the cell nucleus.

\section{Bibliography}

Alexeieff, A. : Mitochondries et corps parabasal chez les Flagellés. Compt. rend. Soc. de biol. T. 80. p. 358-361. 1917.

- : Mitochondries et rôle morphogène du noyau. Ibid. p. 361-363.

_- : Nature mitochondriale du corps parabasal des Flagellés. Ibid. p. 499-502.

— : Sur les mitochondries à fonction gly coplastique. Ibid. p. 510-512.

- - : Sur la fonction glycoplastique du kinétoplaste (=kinetonucleus) chez les Flagellés. Ibid. p. 512-514.

Arnoldi, W.: Materialien zur Morphologie der Meeressiphoneen. II. Bau des Thalloms von Dictyosphaeria. Flora Bd. 105. S. 144-161. 1913.

- et Boenicke.: Sur l'appareil chromidial chez quelques plantes Gymnospèrmes et Angiospèrmes. Saertryk af Biologiske Arbeider Eug. Warming. 1911.

Bělař, K.: Der Formwechsel der Protistenkerne. Jena 1926.

Berg, W.: Über die Wirkung der Nuklealfärbung, besonders der partiellen Hydrolyse mit Normalsalzsäure auf histologische Objekte. Zeitscht. f. mikr.anatom. Forsch. Bd. 7. S. 421. 1926.

Cowdry, N.: Experimental studies on mitochondria in plant cells. Biol. Bull. Vol. 34. 1920.

Dangeard, P. A.: Mémoire sur la terminologie des éléments cellulaires et son application à l'étude des Champignons. Le Botaniste, série 22, fasc. 6. 1931.

Dehorne, A. et C. Hosselet.: Passage de masses nucléolaires dans le cy toplasme des glandes séricigènes des Phryganides. Le nucléo-rouge. Comp. rend. Soc. de biol. T. 99. p. 573.1928.

Dehorne, A. et C. Hosselet.: Le nucléo-rouge dans les cellules séricigènes des Phryganides donne naissance au chondriome. Ibid. p. 575 .

v. Derschau, M. : Wanderung nukleolarer Substanz während der Karyokinese und in lokal sich verdickenden Zellen. Ber. d. d. botan. Ges. Bd. 22. S. 400-411. 1904.

- : Über Analogien pflanzlicher und tierischer Zellstrukturen. Beihefte z. Botan. Cbl. (Orig. Arb.) Bd. 22. S. 167-190. 1907.

- : Beziehungen zwischen Zellkern und Pyrenoiden bei den Chlorophyceen. (Vorl. Mitt.). Ber. d. d. botan. Ges. Bd. 27. S. 99-100. 1909.

- : Beiträge zur pflanzlichen Mitose, Centren, Blepharoplasten. Jahrb. f. wiss. Botan. Bd. 46. S. 103-118. 1909.

- : Zur Frage eines Makronukleus der Pflanzenzellen. Arch. f. Zellforsch. Bd. 4. S. 254-264. 1910.

- Über Kernbrücken und Kernsubstanz in pflanzlichen Zellen. Arch. f. Zellforsch. Bd. 7. 1911.

- : Zum Chromatindualismus der Pflanzenzelle. Arch. f. Zellforsch. Bd 12. S. 220-240. 1914.

Doflein, F.E. Reichenow.: Lehrbuch der Protozoenkunde. 5 Aufl. 1929. Jena.

Fauré-Fremiet, E.: Etude sur les mitochondries des Protozoaires et des cellules sexuelles. Arch. anat. micr. T. 11. p. 457-648. 1909-1910. 
Feulgen, R.: Die Nuklealfärbung. Abderh. Handb. d. biol. Arbeitsmeth. Abt. 5, Lief. 213. S. 1055-1073. 1926.

Feulgen-Frieda Brauns.: Untersuchungen über die Nuklealfärbung. Pflügers Archiv Bd. 203. S. 415. 1924.

Goldschmidt, R.: Der Chromidialapparat in lebhaft funktionierenden Gewebezellen (Vorl. Mitt.). Biol. Cbl. Bd. 24. S. 241-251. 1904.

- : Der Chromidialapparat lebhaft funktionierender Gewebezellen. Zool. Jahrb. Abt. f. Anat. u. Ontog. d. Tiere. Bd. 21. S. 41-140. 1905.

Guilliermond, A. : Observations vitales sur le chondriome des Végétaux et recherches sur l'origine des chromoplastides et le mode de formation des pigments xanthophylliens et carotiniens. Revue gén. d. Botan. T. 31 p. 372-683. 1919.

- : Nouvelles recherches sur les constituants morphologiques du cytoplasme de la cellule végétale. Arch. anat. micr. T. 20, fasc. I. p. 1-210 1923.

- et G. Mangenot.: Revue générale des travaux de cytologie parus de 1910 \& 1925. Revue gén. d. Botan. T. 38-39. p. 1-330. 1928.

Hertwig, R.: Ủber Kernteilung. Richtungskörperbildung und Befruchtung von Actinosphaerium Eichhorni. Abh. d. k. bayer. Akad. d. Wiss. München. Bd. 19. 1898.

-_ : U̇ber Encystierung und Kernvermehrung bei Arcella vulgaris. Festschr. z. 70. Geb. v. G. Kupfer. 1899.

-_ : Die Protozoen und die Zelltheorie. Arch. f. Protist. Bd. 1. S. 1-40. 1902.

Hirschler, J. : Über die Plasmastrukturen (Mitochondrien, Golgischer Apparat u. a.) in den Geschlechtszellen der Ascariden. Arch. f. Zellforsch. Bd. 9. S. 351398. 1913.

- : Sur la relation entre noyau et les composants plasmatiques (appareil de Golgi, vacuome) dans les spermatocytes des Lépidoptères. Comp. rend. Soc. d. biol. T. 101. p. 82-85. 1929.

- - : Sur la relation entre le noyau et les composants plasmatiques (appareil de Golgi) dans les spermatocytes de Palomena viridissima Poda (RhynchotePentatomide). Ibid. p. 269-271.

- - : Sur un appareil de Golgi primaire et secondaire dans les spermatides de Palomena viridissima Poda. Ibid. p. 850-852.

Hollande, A.: La nature et l'origine des inclusions sidérophiles des Blastocystis. Protistologia X. Arch. d. zool. expér. et gén. T. 67. Notes et revues NI. p. 12-17. 1927.

Hosselet, C.: Chondriome et appareil de Golgi dans les glandes séricigènes des Phryganides. Comp. rend. Soc. d. biol. T. 101. p. 87. 1929.

- Le chondriome et les enclaves de la cellule adipeuse chez Culex et quelques Phryganides. Ibid. T. 104. p. 150. 1930.

-_- : Observations cytologiques sur le tube de Malpighi de Culex et de quelques Phryganides. Ibid. T. 104. p. 270. 1930.

- : Aspects du chondriome dans les cellules folliculaires, les cellules nourricières et l'ovocyte chez les Culicides et chez Setodes. Ibid. T. 104. p. 354. 1930.

Kiesel, A.: Chemie des Protoplasmas. Protoplasma-Monographien. Bd. 4. 1930. Berlin.

Koernicke, M.: Der heutige Stand der pflanzlichen Zellforschung. Ber, d. d. botan. Ges. Bd. 21. S. (66-134) (Mitteilungen). 1903.

Kuhlenbeck, H. und K. Voit: Beobachtungen am Kernbild nach Hydrolyse und nach Nuklealfärbung. Anat. Anz. Bd. 74. S. 1-20. 1932.

Lenoir, M.: Evolution des chromosomes hétérotypiques pendant la diacinèse chez l'Equisetum palustre (L). Compt. rendus Soc. de biol. T. 110, p. 77-78. 1932.

Lewitsky, G.: Vergleichende Untersuchung über die Chondriosomen in lebenden und fixierten Pflanzenzellen. Ber. d. d. bot. Ges. Bd. 29 S. 685-703. 1911. 
Lewitsky, G.: Über die Chondriosomen bei Myxomyceten. Zeitschr. f. Botan. Bd. 16. S. 65-89. 1924.

Mascré, M.: Recherches sur le développernent de l'anthère chez les Solanacées. Thèse Sorbonne. 1921.

Meves, Fr.: Ủber das Vorkommen von Mitochondrien bezw. Chondriomiten in Pflanzenzellen. Ber. d. d. botan. Ges. Bd. 22., S. 284-286. 1904.

Meyer, A.: Morphologische und physiologische Analyse der Zelle der Pflanzen und Tiere. Jena. 1920.

Milovidov, P.: Cytologische Untersuchungen an Plasmodiophora brassicae Woron. Arch. f. Protist. Bd. 73. S. 1-46. 1931.

- : La réaction nucléale chez quelques végétaux inférieures. Comp. rend. Soc. d. biol. T. 109, p. 170-171. 1932. (note préliminaire)

Moroff, Th.: Oogenetische Studien. I. Copepoden. Arch. f. Zellforsch. Bd. 2. S. 432-493. 1909.

_- : Zur Kenntnis der Sarkosporidien. Arch. f. Protist. Bd. 35. S. 256-313. 1915.

Nawaschin, S.: Beobachtungen über den feineren Bau und Umwandlungen von Plasmodiophora brassicae Woron. im Laufe ihres intracellularen Lebens. Flora. Bd. 86. S. 404-427. 1899.

Némec, B.: Das Problem der Befruchtungsvorgänge und andere zytologische Fragen. Berlin 1910.

Policard, A. et G. Mangenot.: Action de la témpérature sur le chondriome cellulaire. Comp. rend. d. Acad. d. Sc. T. 174. p. 645. 1922.

Prenant.: Comp. rend. Soc. d. biol. 44. p. 147. 1897.

Radu, V.: Le noyau générateur de mitochondries dans les cellules glandulaires du canal déférent chez Armadillidium vulgare LATR. Comp. rend. Soc. d. biol. T. 103. p. 285-288. 1930.

Reichenow, E. : Ergebnisse mit der Nuclealfärbung bei Protozoen Arch. f. Protist. Bd. 61. S. 144-166. 1928.

Rumiantzev: Observations upon the structure of the chromidial substance in Difflugia pyriformis. Archive of the Russian Protistol. Society Vol. I. p. 100. 1922. (Russian with German summary).

Saguchi, S.: Zytologische Studien. Untersuchungen über die Wechselbeziehung zwischen Karyo- und Zytoplasma. I. Zentronephelium und Chondriom und ihre Beziehung zum Kern etc. Heft I. S. 1-79. 1927. Verlag Maruzen \& Co. Tokyo. Abstr. in Zool. Bericht, Bd. 15. S. 12-13. 1928.

Schiller, J.: Über die Entstehung der Plastiden aus dem Zellkern. (Vol. Mitteil.) Österr. botan. Zeitschr. Bd. 59. S. 89-91. 1909.

- : Beiträge zur Entwicklungsgeschichte und Physiologie des pflanzlichen Zellkerns. I. Die Kerne von Anthitamnion crueiatum f. tenuissima HaUK und A. plumula (ELLIS) Thur. Jahrb. f. wiss. Botan. Bd. 49. S. 267-306. 1911.

Stauffacher, H.: Beiträge zur Kenntnis der Kemstrukturen. Zeitschr. f. wiss. Zool. Bd. 95. S. 1-119. 1910.

- - : Neue Beobachtungen auf dem Gebiete der Zelle usw. Ibid. Bd. 98 S. 478527. 1911.

- : Die Rolle des Nukleins in der Fortpflanzung. Verhandl. d. Schweiz. naturf. Gesell. 94. Jahresvers. Solothurn. Bd. 1. 1911.

Tischler, G.: Ủber die Entwicklung des Pollens und der Tapetenzellen bei RibesHybriden. Jahrb. f. wiss. Botan. Bd. 42. S. 545-578. 1906.

Volkonsky, M.: Sur une nouvelle modification de la technique d'ALTmanN. Bull. hist. appl. T. 4. N5. 1928. Mai. 